\title{
sciendo
}

RESEARCH PAPERS FACULTY OF MATERIALS

SCIENCE AND TECHNOLOGY IN TRNAVA

SLOVAK UNIVERSITY OF TECHNOLOGY

IN BRATISLAVA

2020, Volume 28, Number 46

DOI 10.2478/rput-2020-0011

\section{QUALITY OF PUBLIC TRANSPORT SERVICES IN THE ASPECT OF CITY LOGISTICS REQUIREMENTS}

\author{
Agnieszka PERZYŃSKA ${ }^{1}$ \\ ${ }^{1}$ UNIVERSITY OF ZIELONA GÓRA, FACULTY OF ECONOMICS AND MANAGEMENT \\ UL. PODGÓRNA 50, 65-417 ZIELONA GÓRA, POLAND \\ e-mail: a.perzynska@wez.uz.zgora.pl \\ Received 15 April 2020, accepted 4 June 2020, published 25 June 2020
}

\begin{abstract}
The purpose of the article is to analyse and evaluate public transport in the aspect of city logistics requirements on the example of Zielona Góra. The following study is an attempt to determine the quality of public transport services carried out by the Municipal Public Transport Company. The assessment of public transport is a comprehensive concept referring to more than one parameter. New rolling stock, available information, price of tickets, safety of journeys are only some of the components that affect the assessment of public transport. All the elements that the traveller draws attention to are the factors determining the assessment of public transport. Based on the research carried out in Zielona Góra, despite a small research sample, we can assume that the analysis of the research contributed to the assessment of the level of public transport. After the analysis, the test results confirm the residents' satisfaction with the means of transport. The parameters with unsatisfactory responses provide a signal to improve the quality of services so that subsequent studies will bring greater satisfaction.
\end{abstract}

Key words

City logistics, transportation, public transport

\section{INTRODUCTION}

From the beginning of civilization, the functioning of every human being is closely connected with travelling, and this determines the ability to meet the needs. The demand for transport services is growing rapidly from year to year. This is primarily due to the increase in the needs of customers in terms of flexibility, quality and range of supplies [Kauf. S., Tłuczak A., 2014]. This entails sub-optimal solutions in the field of rolling stock operation, thus reducing the productivity of the means of transport used. Lack of efficiency of logistics solutions intensifies transport congestion even more. The continuous development of public transport is associated with the increase in the population and area of cities, and the development of technology [Ciesielski M., Długosz J., 1992]. The main goal of the article is the analysis and assessment of public transport in the aspect of the city logistics requirements 
on the example of Zielona Góra. The following study is an attempt to determine the quality of public transport services carried out by the Municipal Public Transport Company.

City logistics should be carried out based on the disciplines that appeared at the turn of the 20th and 21st centuries. The subject of urban logistics research are the issues deliberately organized and integrated collection of materials, people and information in the urban agglomeration. These problems include: the issues related to city communication, supplying commercial networks with products, supplying water and energy to the agglomeration, wastewater consumption, support and utilization of waste, construction and maintenance of telecommunications networks, and care for the natural environment of the urban agglomeration and its surroundings [Witkowski 2012].

Attempts at defining urban logistics and explaining its essence by such authors as: J. Szołtysek, E. Gołembska, S. Krawczyk and M. Kiba-Janiak. They deserve attention in the domestic and foreign logistics literature. J. Szołtysek states that urban logistics is the whole process of managing flows of people, loads and information within the city's logistics system, in accordance with the needs and development objectives of the city, while respecting the protection of the natural environment, taking into account that the city is a social organization whose primary goal is to satisfy needs of its users [Szołtysek 2007].

"City logistics plays an increasingly important role in many cities around the world. Recently, the number of passenger cars has increased significantly, and thus problems have increased with the movement of people and material resources in urban agglomerations" [KibaJaniak M., 2012].

"City logistics is a tool for solving problems of functioning of highly urbanized areas microregions, which are urban agglomerations. Urban logistics proposes replacing the current, uncoordinated system of transport flows by a customer-oriented (here: city resident), coordinated between enterprises local logistic system, which is particularly sensitive to the needs of urban agglomeration. Logistics in relation to agglomerations indicate the need to ensure the optimal production and spatial connections, including costs, efficiency and services provided to individual entities, assuming economic and ecological development of the region. The goal of urban logistics is therefore to combine into one all the activity of all business entities operating in the city and to manage this network of events in a way that ensures the desired level of quality of life and management in the city at a minimum level of costs, while taking into account the requirements of ecology. One can also formulate the thesis that urban logistics in this way conditions the further opening of cities to diffusion of innovation or the functioning of cities in the network" [Gołembska E., 2001].

When reviewing the literature, it can be seen that "Urban logistics is a relatively new concept, although it deals with solving the problems arising simultaneously with the beginnings of settlement. The theoretical foundations of knowledge, which is city logistics, are not yet sufficiently developed and shaped, which is why it cannot constitute a separate scientific discipline. Instead, it has many definitions and concepts that bring us closer to systematizing knowledge in logistics and enabling it to be applied to such a multi-functional organization as the city" [Kołodziejski H., 2007].

The tasks of urban logistics include strategic planning of cities and their development. The foreground is the organizational and technical dimensions of logistics flows and an attempt to link the spatial and logistics requirements of most interest groups [Lewandowski, 2004].

City logistics can be defined as planning, implementing and monitoring the economic efficiency and efficiency of the flow of people, loads and related information in urban areas to improve the quality of life of their inhabitants [Kiba-Janiak M., Witkowski J., 2014]. 
The task of urban logistics is strategic planning of cities and their further development. The overarching place is attributed to the organizational and technical role in logistics flows and the study of spatial and logistics relationships faced by most interest groups [Lewandowski K., 2004].

One of the most important goals of urban logistics management is to organise logistics processes so that they contribute to the development of the city. The tasks of urban logistics can be divided into three basic groups [M. Soltysik, 2004]:

- organizational tasks, that is, shaping logistics structures and processes;

- technical tasks, control and IT techniques usedand communication;

- tasks of an economic nature, setting prices, tariffs and fees.

The issues related to the efficient functioning of the city, spatial concentration or distraction relate simultaneously to spatial planning and transport planning. Transport is one of the basic factors determining the level of regional development [Domańska A., 2006].

The goals set for urban logistics are presented in Table 1.

Table 1 General objectives and tasks of city logistics

\begin{tabular}{|c|c|c|c|}
\hline & & Objectives & Tasks \\
\hline Inhabitants & $\begin{array}{l}\text { - convenient location } \\
\text { - reduction of } \\
\text { environmental } \\
\text { pollution } \\
\text { - high throughput and } \\
\text { quality of roads } \\
\text { - an appropriate level } \\
\text { of infrastructure }\end{array}$ & $\begin{array}{l}\text { - convenience, } \\
\text { reliability } \\
\text { - punctuality } \\
\text { - security } \\
\text { - aesthetics }\end{array}$ & $\begin{array}{l}\text { - shortening of time } \\
\text { - elimination of } \\
\text { unnecessary flows } \\
\text { - complexity } \\
\text { - reliable and quick } \\
\text { information }\end{array}$ \\
\hline $\begin{array}{l}\text { Public } \\
\text { sector }\end{array}$ & $\begin{array}{l}\text { - appropriate } \\
\text { investments } \\
\text { - appropriate location } \\
\text { and quality of } \\
\text { infrastructure } \\
\text { - environmental factor }\end{array}$ & $\begin{array}{l}\text { - modernity } \\
\text { - environmental } \\
\text { performance } \\
\text { - adaptation to the } \\
\text { agglomeration } \\
\text { requirements } \\
\text { - availability }\end{array}$ & $\begin{array}{l}\text { - competitiveness } \\
\text { - capital attraction } \\
\text { - rationalization }\end{array}$ \\
\hline $\begin{array}{l}\text { Private } \\
\text { Sector }\end{array}$ & $\begin{array}{l}\text { - appropriate location } \\
\text { - ensuring process } \\
\text { efficiency } \\
\text { - road quality and } \\
\text { capacity } \\
\text { - low costs }\end{array}$ & $\begin{array}{l}\text { - low operating costs } \\
\text { - reliability of means } \\
\text { of transport } \\
\text { - low purchase costs }\end{array}$ & $\begin{array}{l}\text { - elimination of } \\
\text { unnecessary } \\
\text { transport } \\
\text { - specialization }\end{array}$ \\
\hline
\end{tabular}

Adapted from: Tundys B., Logistyka miejska. Koncepcje, systemy, rozwiazania, Difin, Warsaw 2008, p. 163.

City logistics concepts must cover all components: infrastructure, organizational, information and technical, and human. Practical solutions should take into account [Tundys 2008]:

- cities - which, as a geographical area, is a plane of various types of activity, in which various types of logistics processes take place,

- the presence of all types and branches of transport, 
- the concept should include solutions to the most important transport problems in the city and should in principle have a passive attitude to traditional ways of solving them,

- cooperation of participating partners in the implementation of tasks,

- the fact that the implementation of tasks occurs gradually, resulting in the possibility of transformation and reduction of external and internal costs of logistics processes in the city,

- the essence of concentration and joining of transport flows in a given space.

Local authorities should provide the public with convenient transport connections, which are one of the basic life needs that prove the level and quality of life of their inhabitants. We meet the demand for public transport by meeting the most important communication needs.

The volume of demand for each service, including urban transport, is inextricably linked to its real quality as well as the quality perceived by both persons who are not passengers of this type of transport.

Demand for urban transport services is conditioned by the attractiveness of the offer, which is not only directed to the transport service, but also to many aspects of the service. This is related to the statement that enterprises must regularly carry out surveys on the satisfaction of their clients, the results of which will allow to create an optimal offer [Szołtysek J., 2009].

"The efficiency of the urban transport system plays a huge role in shaping socio-economic relations in a given area. Various factors influence the number of transport connections in a city. The most important of them include: spatial development, communication needs, distribution of people in the city, location of jobs and education, as well as distribution of commercial and industrial functions" [Tundys B., 2009].

An extremely important role in every city is played by the transport network, which is an integral part of the urban structure. People managing the city face the problems of ensuring the possibility of the fastest and most convenient journeys within the area of the given center, co nowadays it is a big challenge. This involves carrying out research and analysis in the field of urban transport. These results will allow for further analysis, which will create opportunities for further planning of development and shaping the structure of the modern city [Gadziński J., 2010].

Public transport, as defined in the Act of 16 December 2010 on public collective transport, municipal passenger transport is carried out regularly within the administrative boundaries of the city or: a) city and commune, b) cities, c) neighbouring cities and communes, if an agreement has been concluded or an inter-municipal association has been created for joint implementation of public collective transport [Ministry of Infrastructure 2001]. Thus, urban transport may extend beyond the city area and reach areas that are functionally related to the urban centre.

Public transport is the largest type of passenger transport in Poland in terms of the number of passengers transported. Transportation is carried out in over 260 cities and municipalities, covering 17 million inhabitants. This transport carries about 4 billion passengers annually, which is almost $80 \%$ of the total passenger transport in public road transport.

City transport has a significant impact on the quality of life of the community in a given city. Therefore, the presented purpose of the article refers to the analysis of the functioning of the services provided by the Municipal Transport Company in Zielona Góra. The task was to assess the opinion of the inhabitants of Zielona Góra. 


\section{OPINION SURVEY OF THE INHABITANTS OF ZIELONA GÓRA}

The main purpose of the study conducted for the purposes of this paper was to examine the opinions of passengers using the services of the Municipal Transport Company in Zielona Góra.

The buses of the Municipal Transport Company have been travelling along the streets of Zielona Góra for 66 years. Every day, the city and a dozen surrounding towns are serviced by a fleet of 89 buses.

Within a month, the buses travel about $320,000 \mathrm{~km}$. All rolling stock runs on diesel. To reduce exhaust emissions during the heating of engines, a compressed air installation was brought to all stands at the parking lot [www.mzk.zgora.pl, 2016].

Communication tasks are carried out by a crew of about 300 people, including 174 drivers, mechanics, technical facilities, support staff and administration.

The plant works 24 hours a day on all days of the week. It has 89 low-floor buses in operation. Every day, 72 buses go to the streets of the city, serving residents 7 days a week [www.mzk.zgora.pl, 2020].

Each bus has a telephone connection within the internal cellular network with the dispatch, on-board car computer, electronic ticket validators and a multi-tariff ticket machine issuing the rest (there are two machines in articulated buses). The rolling stock is equipped with hands-free devices announcing stops and electronic boards with line numbers and driving direction. All buses have cameras.

The study was conducted in February 2020. The research sample consisted of 100 randomly selected people from among those at the bus stops in Zielona Gora on the day of the test. The survey was conducted using a questionnaire consisting of 10 questions related to the respondent and their view of the services provided by MZK. The main goal was to be able to complete the survey while waiting for the bus, so it would take 2 to 4 minutes for the respondent to complete the survey.

The questions concerned the manner of using public transport, direct connections, quality of the services, convenience and security. The questions related to a 5-point scale.

The survey evaluated 8 parameters that were considered to be particularly important from the point of view of assessing public transport, which is MZK in Zielona Góra [Table 2].

Based on the research, it should be stated that the respondents were $100 \%$ residents of Zielona Góra. About $92 \%$ of respondents used MZK services every day, and only $8 \%$ several times a week. As many as $66 \%$ of passengers used transport to travel to work, around $26 \%$ to travel to school/university. Other respondents chose private purposes (5\%) and business matters $(3 \%)$ as the destination (Fig. 1).
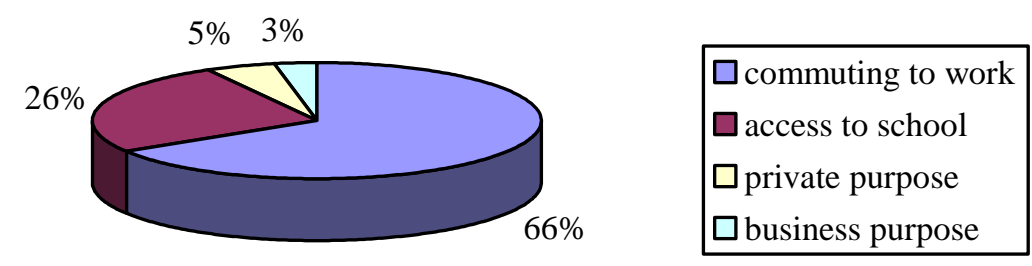

Figure 1 Travel destination of respondents

Source: own study 
The quality of rolling stock was considered to be the most satisfactory parameter indicated by $51 \%$ of respondents as completely satisfactory and satisfactory. The second parameter was the availability of ticket sales points, which was indicated by $48 \%$ of respondents as completely satisfactory.

Another parameter assessed by the respondents as completely satisfactory was the frequency of buses. Almost $46 \%$ of respondents found travelling comfort as completely satisfactory and about $29 \%$ as satisfactory. Only for $2 \%$ of respondents this parameter proved to be completely unsatisfactory. For those surveyed, public transport is a very important form of travelling to both, work and school, and therefore the level of punctuality is determined to be completely satisfactory (32\%).

The most unsatisfactory parameter among the respondents was the ticket price, as many as $21 \%$ considered this result unsatisfactory, and $8 \%$ completely unsatisfactory. Nearly $24 \%$ of respondents gave a sufficiently satisfactory answer.

Table 2 Level of satisfaction of public transport respondents

\begin{tabular}{|c|c|c|c|c|c|}
\hline Tested parameter & 希 & 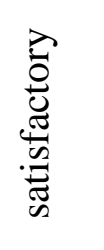 & 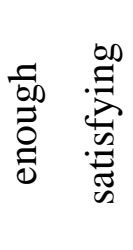 & 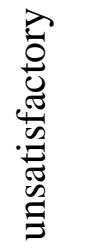 & 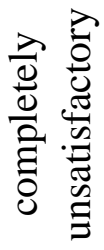 \\
\hline rolling stock quality & $51 \%$ & $23 \%$ & $14 \%$ & $9 \%$ & $3 \%$ \\
\hline transport accessibility & $41 \%$ & $21 \%$ & $17 \%$ & $15 \%$ & $6 \%$ \\
\hline bus frequency & $46 \%$ & $18 \%$ & $20 \%$ & $9 \%$ & $7 \%$ \\
\hline directness of connections & $38 \%$ & $24 \%$ & $15 \%$ & $11 \%$ & $12 \%$ \\
\hline convenience of travelling & $46 \%$ & $29 \%$ & $17 \%$ & $6 \%$ & $2 \%$ \\
\hline availability of ticket sales points & $48 \%$ & $22 \%$ & $21 \%$ & $7 \%$ & $2 \%$ \\
\hline punctuality of buses & $32 \%$ & $26 \%$ & $14 \%$ & $17 \%$ & $11 \%$ \\
\hline travel safety & $38 \%$ & $34 \%$ & $19 \%$ & $6 \%$ & $3 \%$ \\
\hline ticket price & $21 \%$ & $26 \%$ & $24 \%$ & $21 \%$ & $8 \%$ \\
\hline
\end{tabular}

Source: own study 


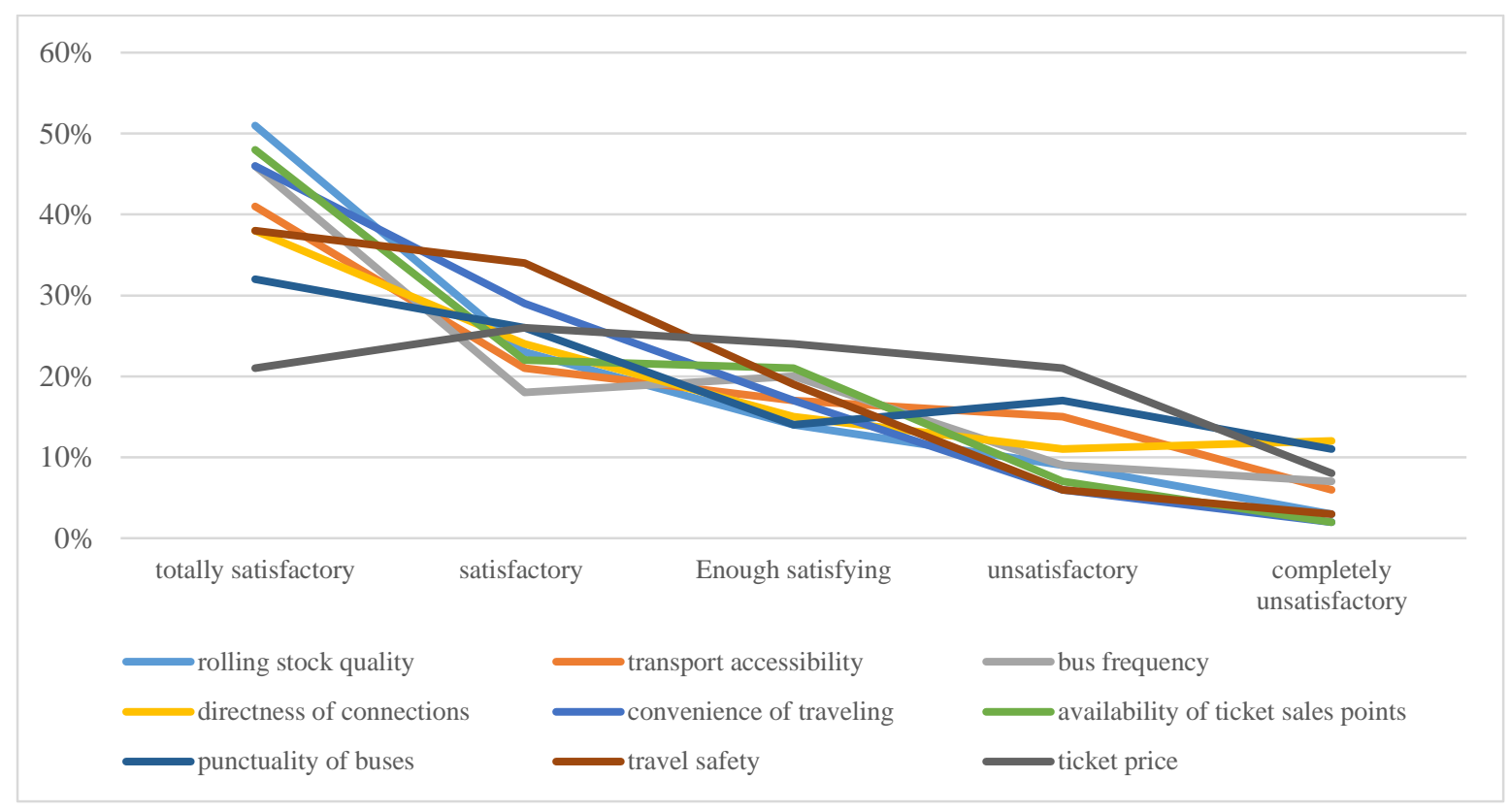

Figure 2 Research results of respondents Source: own study

According to the data obtained on the basis of the conducted research, it can be stated that the respondents indicated the highest satisfaction with the quality of rolling stock. MZK in Zielona Góra has very modern buses, of which the inhabitants are proud. Ticket sales outlets came second. Completely unsatisfactory parameter chosen by the residents was the direct connection and punctuality of buses.

The conducted research gave a general view of the perception of services provided by the Urban Transport Company in Zielona Góra.

\section{CONCLUSION}

Based on the research carried out in Zielona Góra, despite a small research sample, we can assume that the analysis of the research contributed to the assessment of the level of public transport. The analysis confirmed the residents' satisfaction with the means of transport. The parameters related to unsatisfactory answers provide a signal to improve the quality of services, so that the subsequent studies would bring greater satisfaction.

MZK periodically conducts passenger surveys to verify its defects and automatically fix them.

According to the conducted research, MZK verifies the directness of connections, creates new lines, adjusts the peak times so that residents are satisfied. Ticket prices and punctuality of buses is a process supervised by the Public Transport Department. Available automatic signs at the bus stops waiting time calm down impatient passengers.

The research was forwarded to MZK in order to improve the quality of its services and to analyse its activities. MZK analyses the solutions related to improving the flow of people, while taking into account the needs of all users of urban space. It strives to minimise all indicated irregularities.

\section{References}

[1] CIESIELSKI, M., DŁUGOSZ J., WYSZOMIRSKI, Z. 1992. Gospodarowanie $w$ transporcie miejskim (Gospodarowanie w transporcie miejskim). Poznań. 
[2] DOMAŃSKA, A. 2006. Wpływ infrastruktury transportu drogowego na rozwój regionalny (Effect of transport infrastructure on regional development). Warsaw: PWE.

[3] GADZIŃSKI, J. 2010. Ocena dostępności komunikacyjnej przestrzeni miejskiej na przykładzie Poznania, Biuletyn Instytutu Geografii Społeczno-Ekonomicznej i Gospodarki Przestrzennej Uniwersytetu im. Adama Mickiewicza w Poznaniu, Bogucki Wydawnictwo Naukowe (Assessment of urban transport accessibility on the example of Poznań, Bulletin of the Institute of SocioEconomic Geography and Spatial Management at the University of Adam Mickiewicz University in Poznan, Bogucki Scientific Publishing House), Poznań.

[4] GOŁEMBSKA, E. 2001. Kompendium wiedzy o logistyce (Compendium of knowledge about logistics). Warsaw-Poznań.

[5] http://www.mzk.zgora.pl/AutoInternet/rozklad/ 2020

[6] KAUF, S., TŁUCZAK, A. 2014. Logistyka miasta i regionu. Metody ilościowe w decyzjach przestrzennych (City and region logistics. Quantitative methods in spatial decisions). Difin, Warsaw.

[7] KIBA-JANIAK, M. 2012. Studia miejskie (Urban studies), t. 6.

[8] KIBA-JANIAK, M., WITKOWSKI, J. 2014. Modelowanie logistyki miejskiej (Modelling the urban logistics). Warsaw: PWE.

[9] KOŁODZIEJSKI, H. 2007. Modele zarządzania komunikacja miejską (Models of public transport management) Wrocław: Akademia Ekonomiczna.

[10] LEWANDOWSKI K. 2004. Wykorzystanie towarowego transportu szynowego $w$ logistyce miejskiej (The use of rail freight transport in urban logistics). Wrocławia, "Nasz dom i ogród" Wrocław: Publishing House.

[11] SOŁTYSIK, M. 2004. O dynamice zmian w logistyce (On the dynamics aod changes in logistics). [In:] Kierunki rozwoju logistyki w świetle tendencji światowych (Directions of logistics development in the light of global trends), red. M. Sołtysik, Katowice: Academy of Economics in Katowice.

[12] SZOŁTYSEK, J. 2009. Logistyczne aspekty zarządzania przepływami osób i ładunków w miastach (Logistic aspects of managing people and cargo flows in cities). Katowice: Publishing House of Academy of Economics of Karol Adamiecki in Katowice.

[13] SZYMCZAK, M. 2008. Logistyka Miejska (Urban logistics). Poznań.

[14] TUNDYS, B. 2008. Logistyka miejska, Warsaw: Difin Publishing House.

[15] TUNDYS, B. 2009. System transportowy miasta - analiza obszarów dysfunkcji i sposobów ich eliminacji (City transport system - analysis of dysfunction areas and ways to eliminate them), [In:] Wspótczesne systemy transportowe. Wybrane problemy teorii i praktyki (Contemporary transport systems. Selected problems of theory and practice). J. Włoch, R. Janecki, G. Sierpiński. Gliwice: Publishing House of Politechnics of Silesia.

[16] WITKOWSKI, K. 2005. Aspekt logistyki miejskiej w gospodarowaniu infrastruktura transportowa miasta (Aspect of urban logistics in managing the city's transport infrastructure). Papers of the Institute of Law and Administration of the PWSZ in Sulechów.

\section{ORCID}

Agnieszka Perzyńska 0000-0003-1801-0701 